\title{
Beating heart partial ventriculectomy in dogs
}

\author{
Ventriculectomia Parcial com Coração em Movimento em cães \\ Eduardo Santiago Ventura de Aguiar ${ }^{1}$, J oão Eduardo Wallau Schossler ${ }^{1,2}$ Alceu Gaspar Raiser ${ }^{1,2}$, \\ Alessandra Quaresma Ferreira ${ }^{3}$, Claudia Kirst ${ }^{3}$, Mariana Lopes Pellizzari ${ }^{3}$, Camila Spagnol ${ }^{3}$,

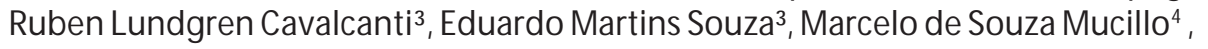 \\ Cássio Ecckert ${ }^{3} \&$ Simone Tostes de Oliveira ${ }^{3}$
}

\begin{abstract}
After valve endocardiosis, dilated cardiomyopathy is the most diagnosed cardiac affection in dogs. Sometimes this disease is unresponsible to medical therapy, in this way surgery becomes necessary to its correction. Unfortunately, dogs do not support cardiopulmonary bypass because its tendency in microtrombus formation in the capillary vessels of the lung circulation. Due to this condition, another surgical alternatives were developed, in order to correct the increase in ventricle size, as the ventricle plication or partial ventriculectomy with the inflow occlusion. However, this kind of technique has its complications, as well the ventricle plication. In plication, a part of necrotic heart tissue still remains, and if the necrosis does not happen, that portion of myocardium keeps its oxygen consumption, leading to heart failure. The partial ventriculectomy with the inflow occlusion is time dependent. For its execution it means that the surgeon gets only four minutes to perform the resection of the dilated ventricle and then suture the remaining defect after the inflow occlusion. The aim of this study is to develop a new technique of heart size reduction, called by the authors Beating Heart Partial Ventriculectomy.
\end{abstract}

Key words: heart, surgery, ventricle, dilatation, cardiomyopathy.

\section{RESUMO}

A cardiomiopatia dilatada, depois da endocardiose valvar, é a afecção cardíaca mais diagnosticada em cães. Por vezes esta doença é irresponsível ao tratamento médico. Nestes casos a cirurgia torna-se necessária na correção da dilatação. Infelizmente, os cães não toleram bem a circulação extracorpórea, pois têm predisposição à formação de microtrombos na circulação pulmonar. Devido a esta condição, outras alternativas cirúrgicas foram desenvolvidas, de forma a corrigir o aumento ventricular, como a plicatura ventricular ou a ventriculectomia parcial com oclusão do afluxo. Contudo, esta técnica possui complicações, assim como a plicatura ventricular. Na plicatura ventricular, ocorre a permanência de uma porção necrótica de miocárdio e, quando isto não acontece, o tecido mantém o seu consumo de oxigênio, levando à falha cardíaca. A ventriculectomia com oclusão do afluxo sanguíneo é tempo-dependente. Para a sua execução o cirurgião precisa realizar a ressecção do ventrículo e a sutura do defeito remanescente em apenas quatro minutos. O objetivo deste estudo é desenvolver uma nova técnica de redução ventricular, denominada pelos autores como Ventriculectomia Parcial com Coração em Movimento.

Descritores: coração, cirurgia, ventrículo, dilatação, cardiomiopatia. 


\section{INTRODUCTION}

Dilated cardiomyopathy is a common disease of large breeds of dogs, consisting in the most common cardiac affection after valve endocardiosis $[5,19]$. It is characterized by the reduction on myocardial contractility, affecting the systolic function [19].

The Batista procedure, or Partial Left Ventriculectomy, was developed to correct the cardiac dilation. Numerous articles mention its application in clinical and experimental situations, reflecting the importance of this surgery $[1,4,9-12,15]$. It is performed with the cardiopulmonary bypass (CPB) in humans [2]. Therefore, the use of the Inflow Occlusion (IO) alouds the Partial Ventriculectomy in dogs. Despite this possibility, the surgeon disposes only of four minutes, at maximum, to resect the myocardial portion and to suture the remaining defect $[7,19]$. Other surgical options are critically needed [17].

In a study where dogs with induced dilated cardiomyopathy by adriamycin, the Left Partial Ventriculectomy improved the cardiac function, so the Partial Ventriculectomy can be faced as a way to prolong the life of a patient, and also to improve its quality of life [4].

The patient selection is very important to the success of the Partial Ventriculectomy [2]. In this way patients with right ventricle failure can be operate as well [3]. In humans, part of the more than 1000 patients have undergone surgery are still alive, or have lived for months or years with an improved quality of life $[2,13,16]$.

The aim of this study is to describe a new technique of Partial Ventriculectomy in dogs, which is feasible and with low costs procedure, dispensing the use of the CPB or the IO, called by the authors as Beating Heart Partial Ventriculectomy.

\section{MATERIALS AND METHODS}

One mongrel dog, with a corporal mass of 13 $\mathrm{kg}$, was choosed for this operation. The patient received as pre-anaesthetic medication acetilpromazine $\left(0.1 \mathrm{mg} \cdot \mathrm{kg}^{-1} \mathrm{IM}\right)$ and morphine $\left(0.4 \mathrm{mg} \cdot \mathrm{kg}^{-1} \mathrm{IM}\right)$. After 15 minutes, the patient was induced to an anaesthetic plan with propofol ( $\left.4 \mathrm{mg} \cdot \mathrm{kg}^{-1} \mathrm{IV}\right)$, trough a peripherical catheter size 20 in the cephalic vein. After the orotracheal intubation the anaesthesia maintained with isoflurane in a universal vaporizer, with $100 \%$ oxygen source. A central venous catheter was placed on the left jugular vein, for measurement of the Central Venous Pressure (CVP) during the operation.

A left intercostal thoracotomy was performed, on the fifth intercostal space. A Finocchieto rib retractor was placed, and the heart was visualized. A pericardiotomy in a "U" figure was performed, and the pericardium flap was sutured to the borders of the thoracotomy. Two peripherical catheters size 22 were placed one at the aorta artery, and the other at the pulmonary artery, to measure the mean arterial pressure (MAP) and pulmonary artery pressure (PAP) $(\mathrm{mm} \mathrm{Hg})$ with two mercury columns, to verify any kind of changes before, during and after the partial ventriculectomy.

The heart was than moved out of the thoracic cavity, without compromising its function. A continue mattress suture pattern were than performed with a 0 polypropylene wire, with a $4 \mathrm{~cm}$ atraumatic needle. The beginning of the suture was not binded. After five points of the suture, the needle was cutted off, and two pieces of a perforated silicon tube was placed transversally in the polypropylene wire, in both extremities. These tubes had the function of avoiding any damage in the myocardium surface. Follow this procedure, each tip of the polypropylene wire were passed inside a plastic tube, consisting in a torniquet of Rommel. Both torniquets were tighten together, but not so much that it could cause ischemia in the tissue, and the myocardial surface adopted the appearance of a crest. The orientation of the crest goes from the conus arteriosus until the apex of the heart. In each extremity of the crest an anchor point were done, in a Wolff pattern, with a 3-0 polypropylene wire, and the needles were maintained. These wires will be further used to execute the ventricle closure. In this way, the surgeon performs the resection of the tissue that compounds the crest, what happened without any bleeding, because of the continue mattress suture.

After the resection, made with a Metzenbaum scissors, a simple continuous suture were done in the remaining heart muscle, with those 3-0 polypropylene wires, trying to make an apposition of the borders. Following its conclusion, the torniquets of Rommel were loosened and the mattress suture is removed. Small bleeding was detected in this part of the procedure, coming from the holes left by the wire. Even so, this 
bleeding stopped in a few seconds. The thoracic cavity was irrigated with warm saline, and a thoracoraphy were executed.

\section{RESULTS}

In spite of the normal aspect of the heart, a considerable amount of myocardium could be resected, measuring $3.7 \mathrm{~cm}$ in length and $1.9 \mathrm{~cm}$ in width. No bleeding was detected when the myocardium was resected, except when the mattress suture was removed. This bleeding was not important, so it stopped within a few seconds, without any kind of hemostatic manner. The mean pressure in the pulmonary artery increases from $8 \mathrm{~mm} \mathrm{Hg}$ (pre-ventriculectomy) to 14 $\mathrm{mm} \mathrm{Hg}$ (post-ventriculectomy), which represents an increase in the ventricle strength. The MAP remained at the normal level, at $100 \mathrm{~mm} \mathrm{Hg}$, and the CVP increased from 3 to $11 \mathrm{~cm} \mathrm{H}_{2} \mathrm{O}$ when the thorax was opened. After the Partial ventriculectomy, it increased to $13 \mathrm{~cm} \mathrm{H} \mathrm{H}_{2} \mathrm{O}$, falling to $6 \mathrm{~cm} \mathrm{H}_{2} \mathrm{O}$ when the thoracoraphy were performed.

\section{DISCUSSION}

Dilated cardiomyopathy is responsible for the most of patients affected by a cardiac disease [5]. The systolic function is affected, because of the reduction on the myocardial contractility [18]. This reduction leads to many clinical findings, such as weight loss, general debility, dyspnea, coughing, jugular venous distension and engorgement of subcutaneous veins and irregularity of pulse and its variations in rate, rhythm and strength $[6,21]$.

The prognosis is reserved to unfavourable, and signs like pleural effusion or pulmonary edema is the worst for the life expectation, which is around six months when the therapeutics is efficient $[5,18]$.

The Partial Left Ventriculectomy is a surgical procedure that is employed to correct the dilated ventricle. It is executed by means of CPB in humans, followed by mitral valvoplasty, when demanded [2]. Despite the use of this resource in humans, dogs do not behave in the same way. These patients have the tendency on microtrombosis in the pulmonary microcirculation, which avoids the application of CPB in this specie [20].

The IO is a procedure that alouds the Partial Ventriculectomy in dogs, but the surgeon disposes only four minutes to procede the ventricle resection and the suture of the remaining muscle $[7,19]$. The technique that is described in this article leads to a more appropriate resection of the ill tissue and a better suture procedure, because it gives the surgeon the possibility of more disposal time, and not only four minutes, time which is considered to long even when the IO is employed.

The ventricle was excised from the conus arteriosus to the apex. The coronary vessels were damaged in one of its branches, but the authors believe that it does not represent such a risk of ischemia, because the ventricular muscle that was irrigated by this branch were resected as well $[8,14]$.

The myocardium supports some tractions and tensions along its structures, testified by the sutures applicated to the ventricle closure [13]. At any moment the tissue seems to lacerate due to the suture. The suture was applied only to make the apposition of the borders, so it may have contribute to its integrity (Figure 1). This kind of suture application seems to lead to a smaller scar formation, which, in association with the fact that the inner subendocardial surface of animals is smooth, would lead to an even smaller chance of arterial embolization [13]. The poor scar formation due to the apposition suture leads to a small fibrosis. In this way arrhythmias are not or at least less expected $[6,21]$.

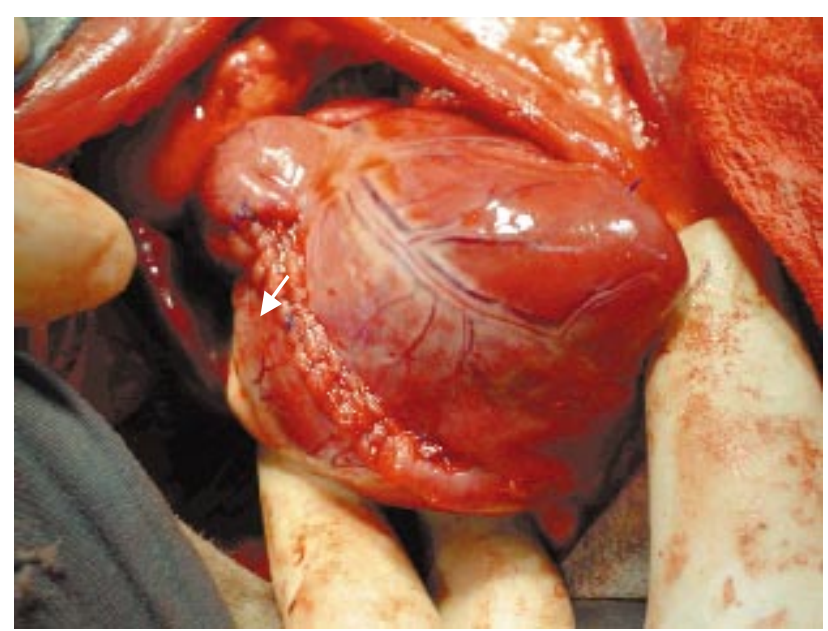

Figure 1. Final aspect of the heart submitted to the Beating Heart Partial Ventriculectomy in the right ventricle. Note the suture area that is still viable, showing the nonischemic characteristic of the suture and the absence of bleeding. A small branch of a coronary artery was ligated with polypropylene suture (arrow).

A simple continuous pattern suture were applicated to close the ventricle defect, with a 3-0 polypropylene wire, which disagrees from the 
affirmation that says the ventriculoraphy must be done with a 0 polyester wire and biological adhesive [3]. The authors believe that the suture as it was described in this article is enough to perform a secure ventricle closure.

\section{CONCLUSIONS}

The results alouds to conclude that the Beating Heart Partial Ventriculectomy is a feasible and with low costs procedure, dispensing the use of the $\mathrm{CPB}$ or the IO. The authors believe that the continuing on this experiment may lead the join of this practice to the existent techniques of dilated cardiomyopathy correction in veterinary patients.

Acknowledgements. The author wants to thanks to BrasMed Veterinária and to VetBrands Pharmaceutics for the support that was given during this research.

\section{REFERENCES}

1 Baretti R., Mizuno A., Buckberg G.D. \& Child J.S. 2000. Batista procedure: elliptical modeling against spherical distension. European Journal of Cardio-thoracic Surgery. 17: 52-57.

2 Batista R. 1999. Partial left ventriculectomy - the Batista Procedure. European Journal of Cardio-thoracic Surgery. 15: 12-19.

3 Birdi A., Bryan A.J., Mehta D., Pryn S., Walsh C., Wilde P. \& Angelini G.D. 1997. Left ventricular volume reduction surgery. International Journal of Cardiology. 62: 29-35.

4 Christiansen S., Stypmann J., Jahn U.R., Redmann K., Fobker M., Gruber A.D., Scheld H.H. \& Hammel D. 2003. Partial left ventriculectomy in modified adriamycin-induced cardiomyopathy in the dog. The Journal of Heart and Lung Transplantation. 22: 301-308.

5 Dunn J.K., Elliott J. \& Herrtage M.E. 2001. Doenças do Sistema Cardiovascular. In: Dunn J.K. (Ed.) Tratado de Medicina de Pequenos Animais. São Paulo: Roca, pp.251-340.

6 Ettinger S.J. \& Suter P.F. 1970. Acquired and congenital heart disease. In: Canine Cardiology. Philadelphia: W.B. Saunders, pp.214-223.

7 Eyster G.E. 1998. Procedimentos Cirúrgicos Cardíacos Básicos. In: Slatter D. (Ed). Manual de Cirurgia de Pequenos Animais. 2.ed. São Paulo: Manole, pp.1075-1104.

8 Ídiz M., Konuralp C. \& Ünal M. 2001. How can we obtain maximal benefits from partial left ventriculectomy? European Journal of Cardio-thoracic Surgery. 19: 537-538.

9 Kabbani S.S., Izzat M.B., Jamil H., Hammoud A., Nabhani F. \& Kabbani L.S. 2000. Early experience with left ventricular volume reduction surgery in Syria. Cardiovascular Surgery. 8: 474-476.

10 Kóllar A., Kékesi V., Soós P. \& Juhász-Nagy A. 2003. Left ventricular external subannular plication: an indirect off-pump mitral annuloplasty method in a canine model. The Journal of Thoracic and Cardiovascular Surgery. 126: 977-982.

11 Konertz K., Hotz H., Kivelitz D. \& Zytowski M. 2002. Five year results after left ventriculectomy in an european heart failure population. The Journal of Heart and Lung Transplantation. 21: 125.

12 Lunkenheimer P.P., Redmann K., Cryer C.W., Sánchez-Quintana D., Anderson R.H. \& Batista R.V. 2000. Late ventricular structure after partial left ventriculectomy. The Annals of Thoracic Surgery. 69: 1257-1259.

13 Lunkenheimer P.P., Redmann K., Cryer C.W., Wübbeling F., Konertz W., Batista R. J. V., Ho S. Y. \& Anderson R. H. 2003. The relationship between structure and function: why does reshaping the left ventricle surgically not always result in functional improvement? Computers in Biology and Medicine. 33: 185-196.

14 Lukenheimer P.P., Redmann K., Florek J.C., Scheld H.H., Hoffmeier A., Cryer C.W., Batista R.V., Stanton J.J., Frota Filho J.D. \& Anderson R.H. 2003. Surgical reduction of ventricular radius by aspirated plication of the myocardial wall: an experimental study. The Journal of Thoracic and Cardiovascular Surgery. 126: 592-596. 
15 Mainwaring R.D., Healy R.M., Murphy J.D. \& Norwood W.I. 2000. Norwood/Batista operation for a newborn with dilated myopathy of left ventricle. The Journal of Thoracic and Cardiovascular Surgery. 120: 612-6115.

16 Moreira L.F.P., Bacal F., Benício A., Bocchi E.A., Higushi M.L., Stolf N.A.G. \& Oliveira S.A. 2001. Fatores prognósticos e evolução da função ventricular em 5 anos de seguimento da ventriculectomia parcial esquerda no tratamento da cardiomiopatia dilatada. Revista Brasileira de Cirurgia Cardiovascular. 16: 275-288.

17 Nair R.U., Williams S.G., Nwafor K.U., Hall A.S. \& Tan L.B. 2001. Left ventricular volume reduction without ventriculectomy. The Annals of Thoracic Surgery. 71: 2046-2049.

18 Nelson R.W. \& Couto C.G. 1992. Doenças miocárdicas do cão. In: Medicina Interna de Pequenos Animais. 2. ed. Rio de Janeiro: Guanabara-Koogan, pp.63-70.

19 Orton C.E. 2002. Cirurgia do Sistema Cardiovascular. In: Fossum T.W. (Ed.). Cirurgia de Pequenos Animais. São Paulo: Roca, pp.638-677.

20 Raiser A.G. 1980. Observações sobre alterações ultramicroscópicas da estrutura pulmonar decorrentes da circulação extracorpórea em cães. 45f. Santa Maria, RS. Dissertação (Mestrado em Medicina Veterinária) - Programa de Pósgraduação em Medicina Veterinária, Universidade Federal de Santa Maria.

21 Sisson D.D. \& Thomas W.P. 1997. Afecções do miocárdio. In: Ettinger S.J. \& Feldman E.C. (Eds). Tratado de Medicina Interna Veterinária. 4.ed. São Paulo: Manole, pp.1382-1429. 